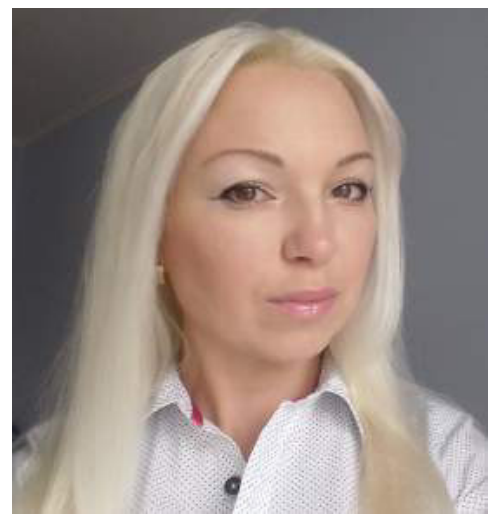

\author{
Марина Василик, \\ кандидат педагогічних наук, \\ ДВНЗ «Прикарпатський національний \\ університет імені Василя Стефаника» \\ (м. Івано-Франківськ)
}

\author{
Maryna Vasylyk, \\ Candidate of Pedagogical Sciences, \\ Vasyl Stefanyk Precarpathian National University \\ (Ivano-Frankivsk) \\ m.vasylyk@yahoo.com.ua
}

УДК [ 371.134:81’243 ]:17.022.1(477.8)

\title{
ВИКОРИСТАННЯ ДУХОВНИХ ЦІННОСТЕЙ КАРПАТСЬКОГО РЕГІОНУ В ІНШОМОВНІЙ ПІДГОТОВЦІ МАЙБУТНІХ ПЕДАГОГІВ ЗАГАЛЬНООСВІТНЬОЇ ШКОЛИ
}

\author{
USAGE OF SPIRITUAL VALUES OF CARPATHIAN REGION \\ IN THE FOREIGN LANGUAGE PREPARATION OF THE FUTURE \\ PEDAGOGUES OF GENERAL EDUCATIONAL SCHOOL
}

\begin{abstract}
у формуванні готовності майбутніх педагогів до професійної діяльності в освітніх закладах Карпатського регіону доцільно використати навчання іноземної мови професійного спрямування для ознайомлення їх з духовними скарбами жителів цього краю. Під час занять з англійської мови з використанням інноваційних технологій студенти оволодівають навичками усного і писемного мовлення, дізнаються про самобутні звичаї, традиції і обряди. морально-етичні норми життя горян, які відображені в усній народній творчості. художній літературі, різних жанрах образотворчого, монументального, декоративно-прикладного мистецтва. Такий підхід сприятиме не тільки формуванню іншомовної комунікативної компетенції майбутніх педагогів, а й прискорить їх адаптацію в специфічних умовах Карпатського регіону.

Ключові слова: англійська мова професійного спрямування, інтеактивні технології навчання, Карпатський регіон, духовні скарби, загальноосвітня школа, майбутні педагоги, іншомовна комунікативна компетенція.

In forming the readiness of the future teachers for professional activity in the educational institutions of the Carpathian region, it is expedient to use the teaching of the foreign language of professional orientation to familiarize them with the spiritual treasures of the inhabitants of this region. During the English lessons with the use of innovative technologies, students learn skills of oral and written speech, they get to know about the original customs, traditions and ceremonies, moral and ethical norms of life of the highlanders, which are reflected in the oral folk creativity, fiction, various genres of fine, monumental, decorative-applied arts. This approach will contribute not only to the formation of the foreign language communicative competence of the future teachers, but will also accelerate their adaptation in the specific conditions of the Carpathian region.

Keywords: English language of professional orientation, interactive learning technologies, Carpathian region, spiritual treasures, general educational school, future teachers, foreign language communicative competence.

В формировании готовности будущих педагогов к профессиональной деятельности в образовательных учреждениях Карпатского региона целесообразно использовать обучение иностранному языку профессиональной направленности для ознакомления их с духовными кладами жителей этого края. Во время занятий по английскому языку с использованием инновационных технологий студенты овладевают навыками устной и письменной речи, узнают о самобытных обычаях, традициях и обрядах, морально-этических нормах жизни горян, которые отображены в устном народном творчестве, художественной литературе, разных жанрах изобразительного, монументального, декоративноприкладного искусства. Такой подход способствует не только формированию иноязычной коммуникативной компетенции будущих педагогов, но и ускоряет их адаптацию в специфических условиях Карпатского региона.

Ключевые слова: английский язык, профессиональная направленность, интерактивные технологии обучения, Карпатский регион, духовные клады, общеобразовательная школа, будущие педагоги, иноязычная коммуникативная компетенция.
\end{abstract}

Постановка проблеми в загальному вигляді та її зв'язок з важливими науковими та практичними завданнями. Глобалізаційні процеси XXI ст., що охопили всі сфери життєдіяльності людини й суспільства, вимагають модернізації освітньої галузі, зміни парадигми педагогічного мислення, продукування нових педагогічних ідей, здатності до інновацій у професійній діяльності та суспільному житті. Загальноцивілізаційні процеси знайшли втілення в концепції «Нова українська школа», що передбачає докорінні зміни в освітньому 
процесі загальноосвітньої школи, отже і в підготовці педагогічних кадрів для цієї ланки національної освіти. Важливим напрямом оновлення професійної педагогічної освіти є підвищення рівня іншомовної компетентності майбутніх педагогів, що дає можливість використовувати духовні надбання інших народів у формуванні майбутніх громадян України конкурентоспроможними на міжнародному ринку праці, спроможними успішно вирішувати актуальні проблеми сьогодення в нашій державі.

Водночас завдання вітчизняної системи освіти полягає в тому, щоб у цьому процесі не втрачати національну самобутність, зберегти і передати нашим сучасникам етнокультурні надбання попередніх поколінь, долучити їх до примноження духовних скарбів рідного народу, що творяться представниками численних етнічних груп, які проживають у різних регіонах України. Практика засвідчує, що їх доцільно використовувати і в іншомовній підготовці майбутніх учителів загальноосвітних навчальних закладів з урахуванням перспектив їх подальшого працевлаштування. У цьому контексті заслуговує на особливу увагу формування професійної готовності вчителів, які працюватимуть у Карпатському регіоні, що відзначається специфічними природно-кліматичними, соціально-економічними і морально-етичними умовами. Врахування цих особливостей у процесі іншомовної підготовки педагогів - важлива умова їх подальшої професійно-педагогічної діяльності в умовах гірської школи.

Аналіз останніх досліджень і публікацій, у яких започатковано розв'язання проблеми. В останні десятиліття питання вдосконалення професійної підготовки майбутніх учителів для шкіл Карпатського регіону привернули увагу таких науковців, як Г.Білавич, О.Будник, М.Євтух, Н.Луцан, С.Мартиненко, М.Марусинець, М.Оліяр, О.Ткачук, О.Цюняк, І.Червінська та ін. Окремі аспекти навчання іноземної мови майбутніх педагогічних працівників висвітлено в працях Т.Близнюк. Проте можливості ознайомлення майбутніх педагогів з надбаннями духовної культури жителів Карпатського регіону в процесі навчання іноземної мови досліджені недостатньо. Цим, власне, і зумовлена актуальність визначеної нами проблеми.

Формування мети статті. Мета статті полягає у виявленні та обгрунтуванні ефективних форм, засобів і прийомів використання етнокультурних надбань мешканців Карпатського регіону у навчанні іноземної мови майбутніх педагогічних працівників освітніх закладів гірського краю.

Виклад основного матеріалу дослідження з повним обґрунтуванням отриманих наукових результатів. На сучасному етапі розвитку суспільства, яке відрізняється глибокими інтеграційними процесами у всіх сферах життя людини, важливого значення набуває формування відкритої до постійних змін особистості, яка усвідомлює важливість будь-якої іноземної мови як засобу спілкування та професійного зростання. Актуальність означеної теми зростає з огляду на переорієнтацію освіти на компетентнісний і гуманістичний підходи, які сприяють успішній соціалізації особистості, розвиткові її творчого потенціалу, самовдосконаленню [4, с. 8].

Викликане проблемами життя оновлення змісту сучасної іншомовної освіти зумовлює необхідність впровадження таких технологій навчання, які відповідали б потребам розвитку особистості, сприяли розкриттю іiі духовно-емоційних, інтелектуальних здібностей, удосконаленню культури спілкування, можливостей самореалізації в складних реаліях сьогодення Української держави, зокрема і в Карпатському регіоні з його самобутніми звичаями, традиціями, обрядами, специфічними умовами життя і праці. Пізнати їх, зрозуміти й усвідомити особливості життя горян, відображені в усній народній творчості, художній літературі, різних жанрах образотворчого, монументального, декоративно-прикладного мистецтва, майбутнім педагогам у значній мірі може допомогти вивчення курсу «Англійська мова професійного спрямування». Вважаємо, що в його змісті повинні знайти відображення й етнокультурні особливості Карпатського регіону, здобутки народної педагогіки його жителів.

Майбутнім працівникам дошкільних навчальних закладів під час засвоєння професійної лексики, формування навичок усного й писемного мовлення пропонуємо ознайомитися з народними іграми та іграшками Гуцульшини. Для цього вони перекладають окремі тексти англійською мовою, наприклад методику підготовки і проведення ігор «Всевидющий», «Квочка», «Хто? Що? Летить?» та розігрують їх. Таким чином студенти збагачують свій лексичний запас, виробляють культуру усного мовлення, навчаються вести діалог. Для прикладу наводимо текст однієї з названих ігор, записаних у Карпатському регіоні педагогом-краєзнавцем з м. Вижниці Чернівецької області Михайлом Іванюком.

Хто? Що? Летить?

Гра «Хто? Що? Летить?» виробляє увагу, розвиває мову, зосередженість. Діти молодшого віку сідають півколом, кладуть два пальці руки на шапку, хустку або іншу річ. Починає гру хтось із старших. Він називає будь-які предмети, ніби вони летять і піднімає свою руку. Якщо пропелер може літати, то треба піднімати руку з двома випрямленими пальцями всім, а якщо предмет літати не може, то хто підняв руку, або не підняв, коли предмет літає, той з гри вибуває.

Хто з гравців залишиться останнім, той веде гру спочатку.

Ось приклад:

- Ворона летить, - всі повинні підняти руку.

- Сорока летить, - усі повинні підняти руку.

- Сорока летить, - руку піднімає тільки ведучий і т.д. [2, с.25].

Основна мета навчання іноземної мови професійного спрямування, як відомо, полягає в формуванні іншомовної професійної компетентності, тобто складного інтеграційного цілого, яке забезпечує компетентне 
професійне спілкування мовою спеціальності в умовах міжкультурної комунікації. Вона передбачає сформованість комунікативних умінь у чотирьох основних видах мовленнєвої діяльності (аудіювання, говоріння, читання, письмо), наявність мовних знань (фонетичних, граматичних, лексичних) та навичок оперування ними. Засобом формування професійної комунікативної компетентності є спілкування, але у тому випадку, якщо воно здійснюється на діяльнісній, ситуативно-обумовленій, мотиваційній основі з використанням професійного змісту як теми спілкування. Звідси випливає, що в процесі формування іншомовної комунікативної компетентності майбутнього фахівця необхідно врахувати специфічні вимоги й умови професійної діяльності, систему виробничих зв'язків, її предметно-технологічний, соціальний і психологічний контексти. Тому, на нашу думку, викладачам іноземної мови слід тісно співпрацювати з профілюючими кафедрами, узгоджуючи тематику занять та стиль мовної поведінки, який найбільш доцільний в тій чи іншій ситуації професійного середовища.

Зазначимо, що вибір ситуацій спілкування, в яких студент використовує мову, має вирішальний вплив на весь процес іншомовної підготовки, а саме: розробку навчальних і робочих програм, постановку цілей, вибір тем спілкування, розробку завдань, тестів, кейсів, підбір текстів та інших навчальних матеріалів, застосування методів навчання. Слід наголосити, що вибір тем і видів діяльності, які сприяють постійній комунікативній взаємодії студентів з питань майбутньої професії, відповідають вимогам студентів, підвищують їхню внутрішню та зовнішню мотивацію.

Досвід колег і власний досвід переконують у тому, що найбільш ефективними технологіями формування іншомовної професійної комунікативної компетентності у навчанні іноземної мови професійного спрямування $€$ інтерактивні види діяльності.

Сутність інтерактивного навчання полягає в тому, що навчальний процес відбувається за умов організації постійної, активної, навчально-пізнавальної взаємодії студентів. Метою його застосування є:

- залучення всіх студентів до активного спілкування на занятті;

- формування позитивної міжособистісної взаємодії у колективі;

- розвиток умінь і навичок виконання різних видів діяльності у стандартних і нестереотипних ситуаціях, умінь критичного і творчого мислення у процесі вирішення професійних завдань;

- навичок роботи у команді.

Перевагами інтерактивного навчання вважаються, насамперед, можливість ефективно використовувати навчальний час, сприяти створенню сприятливих психологічних умов для суб'єктів дидактичного процесу. А також заохочувати студентів до співпраці, що стимулює розвиток їх комунікативних навичок і творчих здібностей.

3 огляду на зазначене необхідно звертати особливу увагу на те, що впровадження інтерактивних форм в оволодіння іноземною мовою буде ефективним тоді, коли зміст педагогічного процесу узгоджується з майбутньюю професійною діяльністю студентів і передбачає моделювання професійно орієнтованих ситуацій, використання рольових ігор, спільне розв'язання проблем з метою досягнення запланованого результату. Саме тому у навчанні майбутніх учителів початкової школи, з орієнтацією на перспективи працевлаштування в гірському регіоні, використовуємо рольові ігри, які мають забезпечити професійно орієнтований розвиток особистості, допомагаючи формувати такі важливі якості, як комунікативність, уміння працювати в парах і групах, проявити мовленнєву самостійність, організаторські та лідерські навички. Виконуючи різноманітні ролі, студенти мають вирішити певну проблемну ситуацію. Підбір проблемних завдань спонукає до використання англійської мови для повсякденного й професійно орієнтованого спілкування.

Ефективним інтерактивним методом у навчанні майбутніх педагогів вважається різновид рольової гри ділова гра. Ділова гра є формою відтворення предметного й соціального змісту професійної діяльності фахівця, моделювання відносин, характерних для цієї діяльності як цілого. Вона дозволяє створювати нові моделі практики, що відповідає цілям актуалізації майбутнього професіоналізму в сучасних умовах. За допомогою ділових ігор у студентів формується цілісне бачення професійної діяльності та теоретичне й практичне мислення в майбутній професійній сфері [1, с.68-71.].

3 цією метою пропонуємо студентам підготувати і провести англійською мовою уроки в початковій школі та такі теми, як «Легенди Українських Карпат», «Казки Гуцульщини», «Мої улюблені казкові герої з Карпатського краю», «Народне мистецтво Гуцульщини», «Таємниці бабусиної скрині», «Карпатські заповідники» та ін. Такий підхід дає їм можливість самостійно ознайомитися з духовними скарбами горян, перекласти зібрані й опрацьовані тексти англійською мовою, дібрати відповідні форми, методи і прийоми донесення їх змісту, образних засобів до учнів початкових класів, залучити молодших школярів до комунікативної іншомовної діяльності.

Ефективним засобом формування в майбутніх педагогів іншомовної комунікативної компетентності є також метод проектів - теоретично-експериментальний напрямок у методиці навчання іноземної мови, який включає такі основні методи, як метод проблемності, творчості, самостійності, колективної діяльності, використання автентичних навчальних матеріалів і завжди орієнтований на самостійну діяльність студентів - індивідуальну, парну, групову, яка виконується протягом визначеного часу. Метод проектів завжди пропонує вирішення певної проблеми, що передбачає, з одного боку, використання різноманітних методів і засобів навчання, а з іншого, інтегрування знань, умінь із різних галузей науки, техніки, культури, освіти, мистецтва. Теми проектів можуть бути найрізноманітніші, але обов'язково пов'язані з подальшою професійною діяльністю педагогів. Майбутнім учителям початкової школи цікаво виконувати проекти на такі теми: «Етнографічна територія 
Гуцульщини», «Основні особливості гуцульського говору», «Громадський побут горян», «Традиційна народна педагогіка Гуцульщини», «Народні звичаї та обряди населення Карпатського регіону», «Усна поетична творчість гуцулів», «Гуцульщина в художній літературі», «Пісні мого села», «Народне мистецтво» тощо. Майбутніх учителів образотворчого мистецтва зацікавлюють проекти, присвячені розвиткові різних видів народного мистецтва вишивка, різьбярство, художнє ткацтво, кераміка, художня обробка металу і шкіри, писанкарство, народний живопис, прикраси з бісеру та ін. Цікавими для них є також заочні екскурсії до музеїв архітектури і народного мистецтва, карпатських заповідників, відвідини відомих майстрів декоративно-прикладного мистецтва тощо.

У процесі їх виконання використовуються дослідницькі методі: визначення проблеми, завдань досліджень, обговорення методів дослідження, оформлення кінцевих результатів, аналіз отриманих даних, підведення підсумків, висновки.

Переконані, що проектне навчання сприяє більш осмисленому і самостійному оволодінню знаннями, має на меті розвиток творчої навчально-пізнавальної діяльності. На заняттях з іноземної мови воно використовується як засіб для активізації творчих можливостей студентів під час вивчення матеріалу та на стадії його закріплення в процесі мовної практики.

Працюючи над проектом, студенти самостійно вчаться добувати необхідну інформацію, користуватися довідковою літературою, залучаючи нові технології, зокрема й мережу Інтернет. Викладач стає їх рівноправним партнером і консультантом.

Для формування іншомовної професійної комунікативної компетентності, на нашу думку, не менш ефективним $€$ навчання публічного виступу з презентацією англійською мовою 3 застосуванням багатофункціональних технологій. Уміння інтерактивного спілкування, які удосконалюються під час навчання, а саме: прийоми ефективної взаємодії доповідача та аудиторії, доречне використання ресурсів мови та невербальних засобів спілкування, проведення ефективних публічних виступів, презентацій та правильне їх оформлення й представлення, стають нагальними в академічному житті студентів і вирішальними у професійній діяльності, відповідають вимогам ринку праці, сприяють кар'єрному росту фахівців різних галузей. Навчання фахової презентації англійською мовою сприяє розвитку професійно орієнтованих комунікативних мовленнєвих компетенцій майбутніх педагогів; дозволяє застосовувати знання, отримані в процесі навчання, у вирішенні практичних завдань, пов'язаних з фахом; забезпечує розвиток культури іншомовлення, ініціативи, самостійності, творчого мислення; веде до створення умов для розвитку вмінь і навичок самоосвіти шляхом організації творчодослідницької навчальної роботи студентів, спрямованої на інтеграцію та актуалізацію знань з різних предметів.

Висновки і перспективи подальших досліджень. Ознайомлення майбутніх педагогів дошкільних навчальних закладів і загальноосвітніх шкіл з духовними надбаннями жителів Карпатського регіону під час навчання англійської мови професійного спрямування допоможе їм не тільки досконало оволодіти культурою іншомовного усного і писемного мовлення, а й сприятиме швидшій адаптації до специфічних для цього краю природно-кліматичних, соціально-економічних, морально-етичних умов життя і праці. 3 цією метою зміст навчального курсу необхідно пов'язувати з майбутньою професійною діяльністю студентів, а для його реалізації використовувати інтерактивні методи навчання іноземних мов.

1. Завалевська О.В. Інтерактивні методи формування професійного самоусвідомлення майбутніх фахівців вищих технічних навчальних закладів/ О.В. Завалевська // Наука і освіта.-2009.-№7.-С.68-71.

2. Іванюк М. Народні ігри та іграшки/Михайло Іванюк.-Вижниця, 1994.-68 с.

\section{Reference}

1. Zavalevska O.V. Interaktyvni metody formuvannia profesiinoho samousvidomlennia maibutnikh fakhivtsiv vyshchykh tekhnichnykh navchalnykh zakladiv/ O.V. Zavalevska // Nauka i osvita.-2009.-№7.-S.68-71.

2. Ivaniuk M. Narodni ihry ta ihrashky/Mykhailo Ivaniuk.-Vyzhnytsia,1994.-68 s.

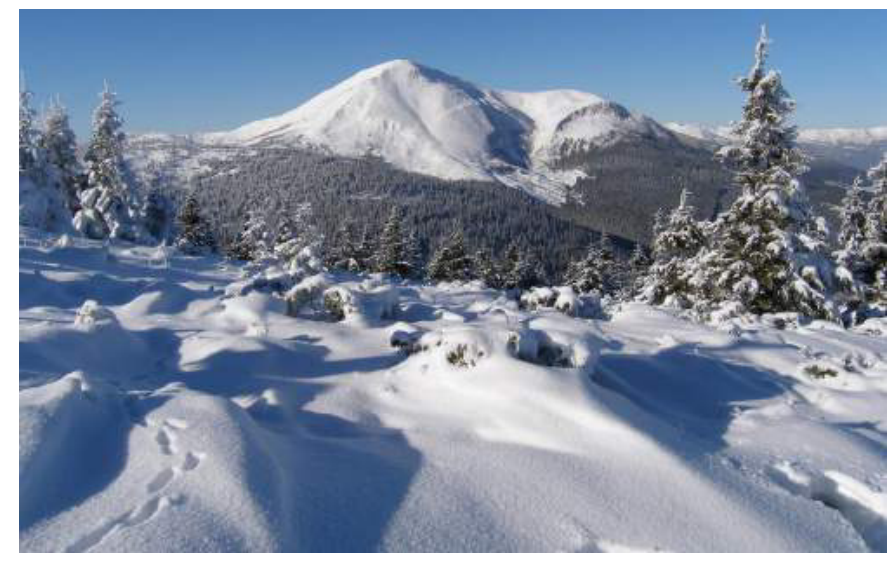

